\section{Factors Driving Behavioural Intentions: Study of Serbian Mobile Operator Customers}

\author{
Vladimir Senić, Veljko Marinković
}

\begin{abstract}
The concept of perceived value is increasingly becoming a subject of interest for authors and researchers in the field of services marketing. Perceived value represents a multi-dimensional concept that consists of a number of components. In the conducted study, four key components were analyzed: emotional value, social value, functional value and monetary value. The objective of the study was to determine the impact of four identified components of value on customer satisfaction, as well as to test impact of customer satisfaction, corporate social responsibility and corporate reputation on behavioural intentions among Serbian mobile operator customers. Research originates from the assumption that to establish long-term relationships with customers, apart from generating customer satisfaction, issues like customer perception of corporate reputation and corporate responsibility are also of great significance.
\end{abstract}

Keywords: perceived value, customer satisfaction, corporate reputation, corporate social responsibility, behavioural intentions. 


\section{PERCEIVED VALUE}

There are various interpretations of perceived value which have resulted in a considerable number of distinct definitions ( $\mathrm{Hu}$ et al. 2009). Nevertheless, these can be allocated into two general categories. The first view proposes that perceived value is a result of the relationship between benefits realized and sacrifices made (Zeithaml 1988, Cronin et al. 2000). The second approach considers perceived value to be a multi-dimensional construct (Sánchez et al. 2006; Sweeney/Soutar 2001). Although there are various interpretations, numerous studies have documented that perceived value has a positive effect on customer satisfaction (Bontis et al. 2007; Hsu 2011; McDougall/Levesque 2000). Certainly, customers' future intentions to continue with patronage of a given firm are dependent on whether the product or service meets their expectations, which are in turn developed through a customer's perceptions about those products or services (Kenyon/Sen 2012). Many of those perceptions are based on how customers perceive different aspects of value. Furthermore, marketing research has shown that value has an important impact on customer satisfaction in addition to behavioural intentions (Ryu et al. 2010).

For the purposes of this research, the multi-dimensional approach to perceived value used by Sheth et al. (1991), as well as Sweeney and Soutar (2001) was employed - including the following four value dimensions: emotional, social, functional and monetary. As Chang (2008) suggests, emotional value is linked with a product's or service's ability to result in stimulating the occurrence of feelings or affective states, which is in line with the proposal that every product or service that has a propensity to result in a change in consumer emotions possesses emotional value (Sheth et al. 1991). Social value is linked with customer aspirations to be associated with desired social groups. In fact, consumers experience products and services as more than just a means of fulfilling their needs or solving their everyday problems. Indeed, they are seen as instruments that have the necessary capability to further advance their social image or improve their self-confidence (Chang 2008). In the context of this study, social value is generated though the fact that mobile operators enable customers to easily get in touch with others (Deng et al. 2010), giving them a sense of constant connectedness even when they are physically separated from others.

Some researchers divide functional value into four elements, including: the functional value of the estab- lishment (installations), the functional value of the contact personnel (professionalism), the functional value of the service purchased (quality) and the functional value price (Roig et al. 2009). In the study, all four components of perceived value have a positive statistically significant impact on customer satisfaction. However, for the purpose of this research, functional value is mainly related to the quality of services rendered, i.e. a mobile operator's potential to deliver services promptly and accurately. The final component of perceived value examined in the study was monetary value. Monetary value refers to whether the mobile operators have provided an adequate service in relation to monetary costs (price) and non-monetary costs (invested time, effort or energy) for obtaining the service. In a research conducted by Deng et al. (2010), statistically significant impact of emotional and functional value on customer satisfaction was confirmed. In line with results of previous studies, we conceptualized the following four research hypotheses:

H1: Functional value has a positive effect on customer satisfaction

$\mathrm{H} 2$ : Emotional value has a positive effect on customer satisfaction

H3: Social value has a positive effect on customer satisfaction

H4: Monetary value has a positive effect on customer satisfaction

\section{SATISFACTION}

Satisfaction is a latent variable that includes a customer's subjective perception regarding the quality of a product or a service. It is often viewed as the feeling that occurs in a customer upon completing a purchase, in the phase following the acquisition of a service (Senić/Marinković 2012). Measuring satisfaction is not based solely on customer experience, but also on their expectations in terms of product/service quality. Therefore, it represents a function of expectations and perceived product or service attributes. Satisfaction is actually an emotional reaction that is manifested in situations when perceived performance of a product or service exceeds expectations (Oliver 1981). Cronin et al. (2000) found that satisfaction - when considered simultaneously with service quality and service value - has a direct impact on behavioural intentions. A study by Clemes et al. (2010) showed that higher levels of satisfaction have positive impact on future 
behavioural intentions. In a similar study performed in the heritage tourism setting it is suggested that the higher levels of satisfaction that heritage tourists experience, the more positive behavioural intentions they will have (Chen/Chen 2010). Finally, Ryu et al. (2009) prove the same relationship in the restaurant setting. Yet, the relationship between satisfaction and behavioural intention in the telecommunications setting has rarely been explored previously. Thus, the following hypothesis is proposed:

H5: Customer satisfaction has a positive effect on behavioural intentions.

\section{CORPORATE SOCIAL RESPONSIBILITY}

With constantly increasing numbers of customers and various stakeholders groups who begin to acknowledge the significance of corporate ethics, many companies are turning towards promoting environmentally sustainable and socially reputable business conduct in their everyday business. This approach to business has gathered pace due to the recent rapid globalization of business (Guo et al. 2009) and an awareness of its possible adverse effects on society in general. Nowadays, companies embark upon many activities that include philanthropy, increased community involvement, greater care for the environment, corporate accountability or corporate citizenship. As suggested by Silberhorn and Warren (2007), many of these activities, although slightly different, are strongly related and represent different manifestations of corporate social responsibility (CSR).

Researchers have not yet come up with the unique definition of CSR (Pirsch et al. 2006). Definitions usually evolve around the notion of a firm's readiness to cater to the needs of local communities, through minimizing harm and maximizing well-being. Probably one of the most frequently used interpretations of CSR is that of Carroll (1999) who views this construct as a synergy of four corporate responsibilities classified into economic, legal, ethical and discretionary (philanthropic) areas (Matten/Crane 2005).

In this study the intention was to examine the significance of CSR on customer's behavioural intentions. This relationship has been the subject of a number of studies in the past. Several studies found that CSR affects - directly or indirectly - responses to products by consumers (Brown/Dacin 1997; Berens et al. 2005; Berens et al. 2007). Sen and Bhattacharya (2001) have expanded the research on CSR by implying that CSR in certain domains can have a direct impact on consumer product reaction in terms of a company's product attractiveness. However, they also implied that under certain conditions, CSR could decrease consumers' intentions to buy a company's products. A particularly interesting piece of research was conducted by Ali et al. (2010), who reported that clients of mobile operators do not consider operator's CRS actions as significant in terms of their future purchase intentions. Thus, we propose the following hypothesis:

H6: Corporate social responsibility has a positive effect on behavioural intentions.

\section{CORPORATE REPUTATION}

Corporate reputation represents one of the elements of a company's marketing communication (Balmer/ Greyser 2006) that is becoming increasingly difficult to control and manage (Brunk 2010). Although, the concept itself has been around since the 1950s, companies have started to exploit it extensively in the last two decades. This has attracted growing interest from researchers, who suggested numerous definitions (Barnett 2012). In fact, in their study, Lange et al. (2010) review over forty articles that discuss and define corporate reputation, grouping the meaning of the concept into three broad categories: a) being overall known, b) being known for something specific and c) generalized favorability - including largely positive perceptions of corporation. For the purposes of this study a definition by Walsh and Beatty (2007) will be adopted. They see customer reputation as 'the customer's overall evaluation of a firm based on his or her reactions to the firm's goods, services, communication activities, interactions with the firm and/or its representatives (e.g. employees, management) and/or known corporate activities'.

In conjunction with CSR, the impact that corporate reputation has on behavioural intentions will be examined, which has rarely been undertaken previously. However, the relationship between corporate reputation and loyalty has seen considerable research. Walsh et al. (2009) found that it has a significant positive impact on customer loyalty. Additionally, Andreassen and Lindestad (1998) reported that corporate reputation indirectly influences customer retention. A study by Nguyen and Leblanc (2001) reported that the level of customer loyalty is likely to be higher when both corporate image and corporate reputation are per- 
ceived favorably by customers. There have also been empirical studies that have confirmed that corporate reputation has a direct impact on loyalty of consumers who are making purchases in the online environment (Caruana/Ewing 2010). In accordance with a review of the existing literature the following hypothesis has been conceptualized:

H7: Corporate reputation has a positive effect on behavioural intentions.

\section{BEHAVIOURAL INTENTIONS}

Although a very complex construct, loyalty is often seen by many researchers and practitioners as one of the key ingredients of an organization's success in the market (Setó-Pamies 2012). Even though most of the initial studies on loyalty largely dealt with the behavioural element (Cunningham 1956), nowadays this concept is often seen as one that comprises of the attitudinal and behavioural element (Day 1969; Jacoby 1971; Dick/Basu 1994; Rauyruen/Miller 2007). Usually, the behavioural constituent of loyalty is manifested through a customer's repeated patronage (Sonmez/ Graef 1998) of services/products from the same company. Oliver (1996) defines the concept as an asserted possibility to engage in a particular behavior. This is in line with the view of Ajzen and Fishbein (1980) who, on a sociological level, view behavioural intention as an individual's decision to behave in a particular manner in the future. In the business context, Zeithaml et al. (1996) identify customer's behavioural intentions with a company's capacity to have customers do a number of things for a company, including a repeat purchase from the company, suggesting to others that they buy from the company or share positive experiences about the company with others. For the purposes of this research, behavioural intention is viewed as a customer's conscious intent to repeatedly use the services of a mobile network provider for a longer period of time.

In accordance with assumed relationships among components of perceived value, customer satisfaction, corporate social responsibility, corporate reputation and behavioural intentions, a research model was conceptualized and is shown in Figure 1.

\section{METHODOLOGY}

The study had several objectives. The effects of four components of perceived value (functional value, emotional value, social value and monetary value) on customer satisfaction were examined. In addition, the statistical significance of the impact of customer satisfaction and corporate reputation on behavioural intentions was tested. As a separate goal, measuring the impact of corporate social responsibility on behavioural intentions can be stressed. The desire would be to determine the extent to which customers perceive socially responsible corporate behavior as an important component in nurturing long-term relationships. It is quite interesting to understand the significance of this variable on behavioural intentions in comparison to the impact of customer satisfaction, which is cre-
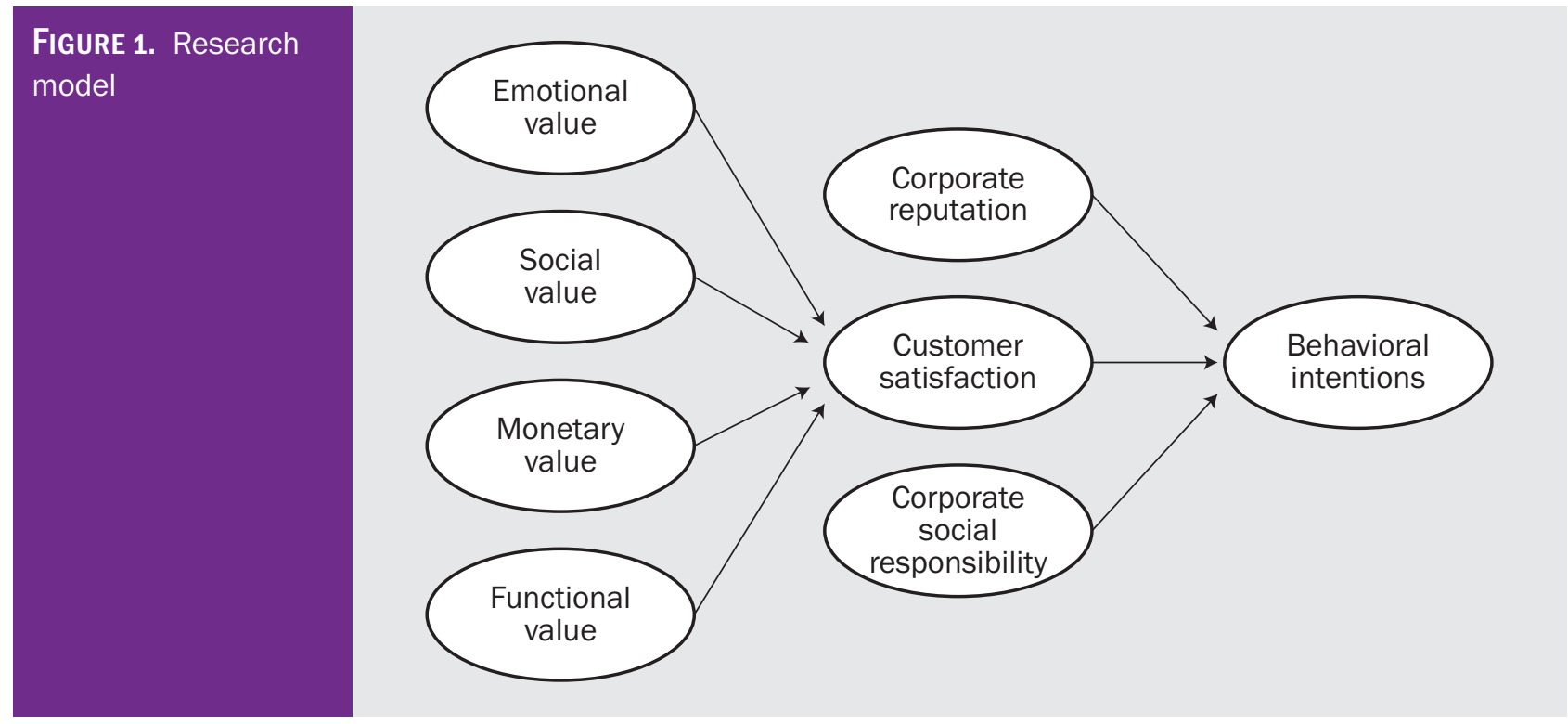
ated under the influence of the combined impact of the four components of perceived value. In this manner it would be possible to clearly determine to which extent the awareness of socially responsible behavior developed among customers in a particular service business sector.

Research was done in the context of the mobile network operator market. The sample consisted of 246 respondents who were subscribers to three European mobile network operators doing business in the Serbian market. The survey used to gather primary data consisted of 28 statements that were evaluated by the respondents via a seven-point Likert scale (1 - I completely disagree; 7 - I completely agree). Prior to distributing the survey to the respondents, several university professors and employees of mobile operators were involved in the focus group, with a goal to identify and eliminate potential issues or ambiguities that respondents might have when filling in the survey.

The selection of statements used to measure the variables of the research model was compiled based on the review of the relevant literature. The basis for conceptualizing statements used to measure functional, emotional and social values was found in the studies of Roig et al. (2009) and Deng at al. (2010). Functional and emotional values were measured by four statements, while three statements were used for measuring social value. Monetary value was measured through four statements that were taken and adapted from Deng et al. (2010) and Johnson et al. (2001). Satisfaction was measured by three items that are found in the American Customer Satisfaction Index (Fornell et al. 1996). The three statements used to measure corporate social responsibility were adapted from Mandhachitara and Poolthong (2011). To measure corporate reputation, four items adapted from Jeng (2011) were used. Finally, Ha and Jang (2010) were the source for three statements used for measuring behavioural intentions.

Data analysis was performed in the Statistical Package for Social Sciences (SPSS 13) and AMOS 18. In the first step, confirmative factor analysis was employed in order to determine the fitness of the proposed model. Thereat, the value for $\chi^{2} / \mathrm{df}$, as well as the value of the following fit indices were obtained: comparative fit index (CFI); Tucker - Lewis index (TLI), incremental fit index (IFI), root mean square error of approximation (RMSEA). In addition, convergent validity, discriminant validity and composite reliability were also examined. Based on Cronbach's alpha coefficient values, the internal consistency of statements used to measure the latent variables was confirmed. By utilizing structural equation modeling, assumed relationships among the variables of the conceptualized model were tested.

\section{RESULTS AND DISCUSSIONS}

Descriptive statistics for the sample showed that $46.7 \%$ of respondents were male and $53.3 \%$ were female. If were observe age structure, the largest portion of respondents falls into the $32-38$ age group (28.9\% of respondents), followed by $25-31$ years old (20.3\%). The remaining respondent groups in the sample were less represented, as show in Table 1. Respondents with bachelor diplomas comprised $46.3 \%$ of the sample, followed by holders of high school diplomas (34.5\%), while the remaining $19.1 \%$ had obtained an associate degree. The sample involved respondents with different occupational profiles.

Prior to examining the assumed relationships among variables, through use of confirmative factor analysis, the fitness of the measurement model was

TABLE 1. Descriptive statistics of respondents' characteristics $(n=246)$

\begin{tabular}{|l|c|c|}
\hline \begin{tabular}{l} 
Demographics \\
\hline Gender
\end{tabular} & Frequency & $\%$ \\
\hline Male & 115 & 46.7 \\
\hline Female & 131 & 53.3 \\
\hline Age & & \\
\hline $18-24$ & 33 & 13.4 \\
\hline $25-31$ & 50 & 20.3 \\
\hline $32-38$ & 71 & 28.9 \\
\hline $39-45$ & 30 & 12.2 \\
\hline $46-52$ & 23 & 9.3 \\
\hline $53-59$ & 19 & 7.7 \\
\hline Over 60 & 20 & 8.1 \\
\hline Education & & \\
\hline High school diploma & 85 & 34.5 \\
\hline Associate's degree & 47 & 19.1 \\
\hline Bachelor's degree or higher & 114 & 46.3 \\
\hline Occupation & & \\
\hline Student & 47 & 19.1 \\
\hline Manager/entrepreneur & 29 & 11.8 \\
\hline Professor, engineer, physician & 44 & 17.9 \\
\hline Clerk & 38 & 15.4 \\
\hline Worker & 28 & 11.4 \\
\hline Vendor & 22 & 8.9 \\
\hline Retired & 23 & 9.3 \\
\hline Other & 15 & 6.1 \\
\hline
\end{tabular}


TABLE 2. Results of confirmative factor analysis

\begin{tabular}{|c|c|c|c|}
\hline Statements & $\begin{array}{l}\text { Factor } \\
\text { loadings }\end{array}$ & AVE & $\mathbf{C R}$ \\
\hline Functional value & & 0.69 & 0.89 \\
\hline My mobile operator is a reliable company & 0.771 & & \\
\hline My mobile operator completely satisfies my needs & 0.809 & & \\
\hline Overall, my mobile operator adequately renders its services & 0.883 & & \\
\hline Information given by staff is very useful to the clients & 0.869 & & \\
\hline Emotional value & & 0.69 & 0.90 \\
\hline I have a good feeling while using service of my mobile operator & 0.894 & & \\
\hline Using service of my mobile operator is giving me satisfaction & 0.866 & & \\
\hline Service offered by my mobile operator are very interesting & 0.771 & & \\
\hline I feel relaxed while using service of my mobile operator & 0.798 & & \\
\hline Social value & & 0.70 & 0.82 \\
\hline As a client of my mobile operator I feel as a socially acceptable person & 0.876 & & \\
\hline $\begin{array}{l}\text { I have a feeling of belongingness to other clients who are also using service of my } \\
\text { mobile operator }\end{array}$ & 0.794 & & \\
\hline Monetary value & & 0.77 & 0.93 \\
\hline Price of services of my mobile operator are adequate & 0.888 & & \\
\hline $\begin{array}{l}\text { Mobile operator has a well balanced relationship between value and price of } \\
\text { services }\end{array}$ & 0.946 & & \\
\hline Price of services are in line with my expectations & 0.876 & & \\
\hline $\begin{array}{l}\text { Price of services of my mobile operator are adequate in comparison to the prices } \\
\text { of other mobile operators }\end{array}$ & 0.788 & & \\
\hline Customer satisfaction & & 0.86 & 0.92 \\
\hline Services of my mobile operator exceeded my expectations & 0.925 & & \\
\hline $\begin{array}{l}\text { Services of my mobile operator are close to services offered by an ideal mobile } \\
\text { operator }\end{array}$ & 0.931 & & \\
\hline Corporate social responsibility & & 0.64 & 0.77 \\
\hline $\begin{array}{l}\text { My mobile operator is focused on sponsoring various manifestations to an } \\
\text { adequate extent }\end{array}$ & 0.679 & & \\
\hline My mobile operator provides student scholarships & 0.903 & & \\
\hline Corporate reputation & & 0.69 & 0.87 \\
\hline My mobile operator is very respected company in its branch of business & 0.842 & & \\
\hline My mobile operator is a professional company & 0.897 & & \\
\hline My mobile operator is a stable company & 0.748 & & \\
\hline Behavioral intentions & & 0.79 & 0.92 \\
\hline In future, I will continue using service of my mobile operator & 0.788 & & \\
\hline I am willing to recommend my mobile operator to others & 0.928 & & \\
\hline I am willing to share nice impressions regarding my mobile operator with others & 0.949 & & \\
\hline
\end{tabular}

tested. In the first step of the analysis, four statements which have low item-to-total correlation were excluded. The model that finally surfaced has an adequate fit. The proportion between the chi-square value and degrees of freedom is within an acceptable range $\left(\chi^{2}=\right.$ 534.624; $\left.\mathrm{df}=224, \mathrm{p}<0.01 ; \chi^{2} / \mathrm{df}=2.38\right)$. This value is lower than 3 , which is in accordance with the recommendation suggested by Carmines and McIver (1981). Other fit models also have acceptable val- ues $(\mathrm{CFI}=0.941 ; \mathrm{TLI}=0.927 ; \mathrm{IFI}=0.942 ; \mathrm{RMSEA}$ $=0.075)$. Given that the value of the CFI, TLI and IFI indices were greater than the 0.9 threshold (Byrne 1998), and the value of RMSEA is lower than 0.008 (Hair et al. 2006), it can be inferred that an adequate model was conceptualized.

All factor loadings are greater than 0.6 and their values are significant at the 0.01 level. The average variance extracted (AVE) of all constructs is higher than 
TABLE 3. Tests of hypothesized relationships

\begin{tabular}{l|c|c|}
\hline Hypothesis & Estimates & Conclusion \\
\hline H1: Functional value $\rightarrow$ customer satisfaction & $0.611^{* *}$ & Supported \\
\hline H2: Emotional value $\rightarrow$ customer satisfaction & $0.023^{\text {ns }}$ & Not supported \\
\hline H3: Social value $\rightarrow$ customer satisfaction & $0.215^{* *}$ & Supported \\
\hline H4: Monetary value $\rightarrow$ customer satisfaction & $0.405^{* *}$ & Supported \\
\hline H5: Customer satisfaction $\rightarrow$ behavioral intentions & $0.452^{* *}$ & Supported \\
\hline H6: Corporate social responsibility $\rightarrow$ behavioral intentions & $0.136^{\text {ss }}$ & Not supported \\
\hline H7: Corporate reputation $\rightarrow$ behavioral intentions & $0.252^{* *}$ & Supported \\
\hline
\end{tabular}

** Significant at 0.01 level.

ns not significant

a threshold of 0.5 which satisfies the condition of convergent validity (Fornell/Larcker 1981). In the case of the model used, the AVE values of latent variables are within the range $0.64-0.86$ (Table 2). Given that the AVE value of each individual variable is greater than the squared correlations between given and other variables, discriminatory validity was also assured. In addition, all the coefficient composite reliability values were greater than 0.60 (Bagozzi/Yi 1988). Based on Cronbach's alpha coefficient value analysis, internal statement consistency, within each variable of conceptualized model, was analyzed. In the case of all variables, Cronbach's alpha coefficient value was greater than the 0.7 threshold suggested by Nunnally (1978).

The structural equation model was used to test all hypotheses. The fit of the structural model was sufficient $\left(\chi^{2}=590.411 ; \mathrm{df}=230 ; \mathrm{p}<0.01 ; \chi 2 / \mathrm{df}=\right.$ 2.57; $\mathrm{CFI}=0.932 ; \mathrm{TLI}=0.918 ; \mathrm{IFI}=0.932 ;$ RMSEA $=$ 0.080 ). The model included eight latent variables that were grouped at three levels. At the first level, four types of perceived value are placed and their impact on customer satisfaction (hypotheses 1-4) was tested. The second level, apart from customer satisfaction, comprises of corporate social responsibility and corporate reputation. In the study, the impact of the three variables on behavioural intentions was measured and was placed in the third level of the research model (hypotheses 5-7).

Five out of the seven relationships that were tested emerged as statistically significant. The results show that functional, monetary and social values are statistically significant triggers of satisfaction. Functional value turned out to have the strongest impact (estimate $=0.611, \mathrm{p}<0.01)$, followed by the impact of monetary value (estimate $=0.405, \mathrm{p}<0.01$ ) and social value (estimate $=0.215, \mathrm{p}<0.01$ ) - thus, confirming hypotheses $\mathrm{H} 1, \mathrm{H} 3$ and $\mathrm{H} 4$ (Table 3). The given results imply that the reliability of the delivered service, professionalism and the quality of given information, price, as well as the feeling of belongingness to a referral group are the major factors in creating customer satisfaction. On the other hand, whether emotional value has a statistically significant impact on satisfaction was not confirmed, thereby rejecting hypothesis H2. Clearly, a customer's emotions related to the use of a mobile operator's service do not have an important role in creating customer satisfaction in comparison to functional, monetary or social value.

Customer satisfaction surfaced as a statistically significant antecedent of behavioural intentions (estimate $=0.452, \mathrm{p}<0.01$ ), thus confirming hypothesis $\mathrm{H} 5$. The impact of corporate reputation on behavioural intentions is weaker compared to the impact of customer satisfaction, but it is also statistically significant (estimate $=0.252, \mathrm{p}<0.01$ ), which in turn confirms hypothesis H7. Unlike satisfaction and corporate reputation, the conducted study did not establish a statistically significant impact of corporate social responsibility on behavioural intentions, thus rejecting hypothesis H6. Evidently, socially responsible activities of the mobile network operator, unlike customer satisfaction, are not positioned in the mind of customers as a factor that will have an impact on them when considering continued patronage with a given mobile operator or whether they would be willing to recommend their operators to friends and acquaintances.

\section{CONCLUSIONS}

The study investigated the impact of four types of perceived value on customer satisfaction, as well as the impact of customer satisfaction, corporate reputation and corporate social responsibility on behavioural intentions and as such, it offers useful theoretical and managerial implications. In a theoretical context, the 
research contributes to the existing literature, given the fact that the concept of perceived value was analyzed through four components - functional, emotional, social and monetary. In that manner, the study rather holistically accents the role of perceived value in creating customer satisfaction. In fact, in a limited number of studies, perceived value is expressed through the four components. The results indicated that functional and monetary values have the most significant impact on customer satisfaction. The role of social value is somewhat weaker, but it is also statistically significant. The sense of social connectedness with other clients, on one hand and the impact of referent groups on the other, do drive customer satisfaction to a great extent. It is important to stress that the study did not, however, confirm a significant impact of emotional value on customer satisfaction.

The originality of the research is reflected in the fact that the impact of corporate reputation and corporate social responsibility on behavioural intentions was tested. It is particularly important to stress that corporate social responsibility gave a specific characteristic to the conceptualized model. By using this variable, the extent to which the socially responsible activities of mobile network operators actually influence client attitude towards future use of operator's services and willingness to recommend operator to others, could be determined. Nevertheless, the findings revealed that customer satisfaction is the single most important driver of behavioural intentions. Client perceptions of corporate reputation also have an impact on behavioural intentions. However, the results of the research did not confirm a significant impact of corporate social responsibility on behavioural intentions. Evidently, in the client's eyes, sense of satisfaction and a company's reputation are the most important factors when deciding on continuing a business relationship with a mobile operator, while, on the other hand, it appears that clients still do not attribute much significance to mobile operator's socially responsible activities, such as the sponsorship of events or the provision of student scholarships. However, this could be attributed to the social fabric of the respondents, given that Serbia is a former socialist country whose inhabitants have a rather different perception of corporate citizenship in comparison with their Western counterparts. In a socialist system it was expected that a state-run and state-owned company supports local sports teams, cultural or social events, whenever such support was needed or demanded. After all, the comprehension of corporate social responsibility is different even among the traditionally capitalist countries - as Fifka (2013) points out in his study on perceptions of corporate citizenship in the United States and Germany.

With regards to managerial implications, it is necessary to emphasize that management needs to direct its attention towards improving functional and monetary aspects of value. Reliability, professionalism of staff, the provision of valuable information and service pricing, represent the most important drivers of customer satisfaction. Interestingly, results reveal that the emotional connectedness of clients with mobile operators does not lead to satisfaction. Obviously, some other elements of the service offering - such as, functionality and price - are seen as more significance by the clients. Therefore, it is important that management improves the level of affective loyalty regarding company activities. It is highly advisable that management activities are directed towards better linked services relating to self-concept and client lifestyle.

Given that satisfaction has surfaced as a significant antecedent of behavioural intentions, management should be aware of the fact that in given market conditions, focus on functional and monetary values can facilitate improving customer satisfaction, which in turn increases a client's willingness to recommend the operator and a readiness to use an operator's services in the future. Strong corporate reputation is one more factor could be considered as a cornerstone of nurturing long-term relationships with the clients. Although corporate social responsibility did not appear as a significant antecedent of behavioural intentions, management should not downscale its socially responsible activities. Namely, successful marketing campaigns can strengthen customer loyalty - particularly towards those companies whose actions, such as providing student scholarships, assist in improving the quality of a society and the overall national economy.

\section{LIMITATIONS AND FUTURE RESEARCH}

The study has several limitations. The conceptualized research model is tested in the domain of mobile network operators, but it would be desirable for this model to be applied to other service industries as well. Such an approach would allow for the comparative analysis of results across different service industries. It could then be determined if the four components of perceived value have a different degree of impact on customer satisfaction in different service settings. In addition, it would be interesting to examine if corporate social responsibility appears as a significant trigger in other service businesses. It would also be desirable 
to conduct studies in successive time intervals, which would allow for more profound tracking of customer perceptions concerning the variables of the suggested model. It would be useful for future studies to create new models that would include new variables. For instance, the concept of loyalty could be analyzed by utilizing two components - attitudinal and behavioural loyalty. In addition, it would be useful for the model variables to be measured through a greater number of statements which, in particular, refer to social value and corporate social responsibility. Furthermore, it could prove to be very insightful to conduct this study in one of the "traditionally" capitalist countries, since the results might differ substantially - rendering corporate social responsibility as a significant trigger of customer's future behavioural intentions.

\section{References}

1. Ajzen, I. and Fishbein, M. (1980), Understanding Attitudes and Predicting Social Behavior. Englewood Cliffs: Prentice Hall.

2. Ali, I., Rehman, K.U., Yilmaz, A.K., Nazir, S. and Ali, J.F. (2010), "Effects of corporate social responsibility on consumer retention in cellular industry of Pakistan", African Journal of Business Management, Vol. 4, No. 4, p. 475-485.

3. Andreassen, T.W. and B. Lindestad (1998), "The effect of corporate image in the formation of customer loyalty", Journal of Service Research, Vol. 1, No. 1, p. 82-92.

4. Bagozzi, R.P. and Yi, Y. (1988), "On the evaluation of structural equation models", Journal of the Academy of Marketing Science, Vol. 16, No. 1, p. 74-94.

5. Balmer, J.M.T. and Greyser, S.a. (2006), "Corporate marketing: Integrating corporate identity, corporate branding, corporate communications, corporate image and corporate reputation", European Journal of Marketing, Vol. 40, No. 7/8, p. 730-741.

6. Barnett, M.L. and Pollock, T.G. (2012), The Oxford Handbook of Corporate Reputation. Oxford: Oxford University Press.

7. Berens, G., van Riel, C.B.M. and van Bruggen, G.H. (2005), "Corporate associations and consumer product responses: the moderating role of corporate brand dominance", Journal of Marketing, Vol. 69, No. 3, p. 35-48.

8. Berens, G., van Riel, C.B.M. and van Rekom, J. (2007), "The CSR-quality trade-off: when can corporate social responsibility and corporate ability compensate each other?", Journal of Business Ethics, Vol. 74, No. 3, p. 233-52.

9. Bontis, N., Booker, L.D. and Serenko, A. (2007), "The mediating effect of organizational reputation on customer loyalty and service recommendation in the banking industry", Management Decision, Vol. 45, No. 9, p. 1426-1445.

10. Brown, T.J. and Dacin, P.A. (1997), "The Company and the Product: Corporate Associations and
Consumer Product Responses," Journal of Marketing, Vol. 61, No. 1, p. 68-84.

11. Byrne, B.M. (1998), Structural equation modelling with LISREL, PRELIS, and SIMPLIS: Basic concepts, applications, and programming. Mahwah, NJ: Lawrence Erlbaum.

12. Carmines, E. and McIver, J. (1981), Analyzing models with unobserved variables: Analysis of covariance structures. In G. Bohmstedt and E. Borgatta (Eds.). Social measurement: Current issues. Beverly Hills, CA: Sage.

13. Carroll, A.B. (1999), "Corporate social responsibility: evolution of a definitional construct", Business and Society, Vol. 38, No. 3, p. 268-95.

14. Caruana, A. and Ewing, M. T. (2010), "How corporate reputation, quality, and value influence online loyalty", Journal of Business Research, Vol. 63, No. 9/10, p. 1103-1110.

15. Chang, H.-S. (2008), "Increasing hotel customer value through service quality cues in Taiwan", The Service Industries Journal, Vol. 28, No. 1, p. 73-84.

16. Chen, C.-F. and Chen, F.-S. (2010), "Experience quality, perceived value, satisfaction and behavioral intentions for heritage tourists", Tourism Management, Vol. 31, No. 1, p. 29-35.

17. Clemes, M.D., Gan, C. and Ren, M. (2010), "Synthesizing the Effects of Service Quality, Value, and Customer Satisfaction on Behavioral Intentions in the Motel Industry: An Empirical Analysis", Journal of Hospitality \& Tourism Research, Vol. 35, No. 4, p. 530-568.

18. Cronin, J. Jr, Brady, M. and Hult, T. (2000), "Assessing the effects of quality, value, and customer satisfaction on consumer behavioral intentions in service environments", Journal of Retailing, Vol. 76, No. 2, p. 193-218.

19. Cunningham, R.M. (1956), "Brand loyalty - what, where, how much?", Harvard Business Review, Vol. 34, No. 1, p. 116-28. 
20. Day, G.S. (1969), "A two dimensional concept of brand loyalty", Journal of Advertising Research, Vol. 9, No. 3, p. 29-36.

21. Deng, Z., Lu, Y., Wei, K.K. and Zhang, J. (2010), "Understanding customer satisfaction and loyalty: An empirical study of mobile instant massages in China"; International Journal of Information Management, Vol. 30, No. 4, p. 289-300.

22. Dick, A.S. and Basu, K. (1994), "Customer loyalty: toward an integrated conceptual framework", Journal of Academy of Marketing Science, Vol. 22, No. 2, p. 99113.

23. Fornell, C., Johnson, M.D., Anderson, E.W., Jaesung, C. and Bryant, B.E. (1996), "The American customer satisfaction index: nature, purpose and findings", Journal of Marketing, Vol. 60, No. 4, p. 7-18.

24. Fornell, C. and Larcker, D.F. (1981), "Evaluating structural equation models with unobservable variables and measurement error", Journal of Marketing Research, Vol. 18, No. 1, p. 39-80.

25. Guo, J., Sun, L. and Li, X. (2009), "Corporate social responsibility assessment of Chinese corporation", International Journal of Business Management, Vol. 4, No. 4, p. 54-57.

26. Ha, J. and Jang, S. (2010), "Perceived values, satisfaction and behavioral intentions: The role of familiarity in Korean restaurants", International Journal of Hospitality Management, Vol. 29, No. 1, p. 2-13.

27. Hair, Jr. J. F., Black, W. C, Babin, B., Anderson R. and Tatham, R. (2006), Multivariate Data Analysis (6th ed.). Upper Saddle River, NJ: Prentice Hall.

28. Hsu, K.-T. (2011), “The Advertising Effects of Corporate Social Responsibility on Corporate Reputation and Brand Equity: Evidence from the Life Insurance Industry in Taiwan", Journal of Business Ethics, Vol. 109, No. 2, p. 189-201.

29. Hu, H.-H. (Sunny), Kandampully, J. and Juwaheer, T.D. (2009), "Relationships and impacts of service quality, perceived value, customer satisfaction, and image: An empirical study", The Service Industries Journal, Vol. 29, No. 2, p. 111-125.

30. International Telecommunication Union (2011), The world in 2013 - ICT facts and figures. Genève: ICT Data and Statistics Division.

31. Jacoby, J. (1971), "A model of multi-brand loyalty", Journal of Advertising Research, Vol. 11, No. 3, p. 2531.

32. Jeng, S.-P. (2011), “The effect of corporate reputations on customer perceptions and cross-buying intentions", The Service Industries Journal, Vol. 31, No. 6, p. 851-862.

33. Johnson, M.D., Gustafsson, A., Andreassen, T.W., Lervik, L. and Cha J. (2001), "The evolution and future of national customer satisfaction index models",
Journal of Economic Psychology, Vol. 22, No. 2, p. 217 245.

34. Kenyon, G. and Sen, K. (2012), "A model for assessing consumer perceptions of quality", International Journal of Quality and Service Sciences, Vol. 4, No. 2, p. 175-188.

35. Lange, D., Lee, P.M. and Dai, Y. (2010), “Organizational Reputation: A Review”, Journal of Management, Vol. 37, No. 1, p. 153-184.

36. Mandhachitara, R. and Poolthong, Y. (2011), “A model of customer loyalty and corporate social responsibility“, Journal of Services Marketing, Vol. 25, No. 2, p. 122-133.

37. McDougall, G. and Levesque, T. (2000), “Customer satisfaction with services: putting perceived value into the equation", Journal of Services Marketing, Vol. 14, No. 5, p. 392-410.

38. Nguyen, N. and Leblanc, G. (2001) "Corporate image and corporate reputation in customers' retention decisions in services", Journal of Retailing and Consumer Services, Vol. 8, No. 4, p. 227-236.

39. Nunnally, J.C. (1978), Introduction to psychological measurement. New York: McGraw-Hill.

40. Oliver, R.L. (1981), "Measurement and evaluation of satisfaction processes in retail settings", Journal of Retailing, Vol. 57, No. 3, p. 25-48.

41. Oliver, R.L. (1996), Satisfaction: A Behavioral Perspective on the Consumer, New York: McGraw-Hill.

42. Pirsch, J., Gupta, S. and Grau, S.L. (2006), “A framework for understanding corporate social responsibility programs as a continuum: An exploratory study", Journal of Business Ethics, Vol. 70, No. 2, p. 125-140.

43. Portio Research (2012), Mobile messaging futures 2012-2016: Analysis and growth forecasts for mobile messaging markets worldwide. www.portioresearch. com/en/free-mobile-factbook.aspx. Accessed April 27, 2013.

44. Rauyruen, P. and Miller, K. E. (2007), "Relationship quality as a predictor of B2B customer loyalty", Journal of Business Research, Vol. 60, No. 1, p. 21-31.

45. Roig, J.C.F, García, J.S. and Moliner Tena, M.Á. (2009), "Perceived value and customer loyalty in financial services., The Service Industries Journal, Vol. 29 , No. 6, p. 775-789.

46. Ryu, K., Han, H. and Jang, S. (Shawn) (2010), "Relationships among hedonic and utilitarian values, satisfaction and behavioral intentions in the fastcasual restaurant industry", International Journal of Contemporary Hospitality Management, Vol. 22, No. 3, p. 416-432.

47. Sánchez, J., Callarisa, L., Rodríguez, R.M. and Moliner, M.Á. (2006), "Perceived value of the purchase of a tourism product", Tourism Management, Vol. 27, No. 3, p. 394-409. 
48. Sen, S. and Bhattacharya, C.B. (2001), "Does Doing Good Always Lead to Doing Better? Consumer Reactions to Corporate Social Responsibility", Journal of Marketing Research, Vol. 38, No. 2, p. 225-243.

49. Senić, V., and Marinković, V. (2013), "Patient care, satisfaction and service quality in health care", International Journal of Consumer Studies, Vol. 37, No. 3, p. 312-319.

50. Setó-Pamies, D. (2012), “Customer loyalty to service providers: examining the role of service quality, customer satisfaction and trust", Total Quality Management \& Business Excellence, Vol. 23, No. 11/12, p. 1257-1271.

51. Sheth, J.N., Newman, B.I. and Gross, L.G. (1991), "Why we buy what we buy: A theory of consumption values", Journal of Business Research, Vol. 22, No. 2, p. 159-170.

52. Silberhorn, D. and Warren, R.C. (2007), "Defining corporate social responsibility: A view from big companies in Germany and the UK", European Business Review, Vol. 19, No. 5, p. 352- 372.

53. Sonmez, S.F. and Graefe, A.R. (1998), "Determining future travel behavior from past travel experience and perceptions of risk and safety", Travel Research, Vol. 37, No. 4, p. 171-177.

54. Sweeney, J.C. and Soutar, G. (2001), “Consumer perceived value: The development of multiple item scale", Journal of Retailing, Vol. 77, No. 2, p. 203-220.

55. Walsh, G. and Beatty, S.E. (2007), "Customerbased corporate reputation of a service firm: scale development and validation", Journal of the Academy of Marketing Science, Vol. 35, No. 1, p. 127-143.

56. Walsh, G. Mitchell, V.-W., Jackson, P.R. and Beatty, S.E. (2009), "Examining the Antecedents and Consequences of Corporate Reputation: A Customer Perspective", British Journal of Management, Vol. 20, No. 2, p. 187-203.

57. Zeithaml, V.A, Berry, L. and Parasuraman, A. (1996), "The behavioral consequences of service quality", Journal of Marketing, Vol. 60, No. 2, p. 31-46.

58. Zeithaml, V.A. (1988), "Consumer perceptions of price, quality and value: A means-end model and synthesis of evidence", Journal of Marketing, Vol. 52, No. 3, p. 2-22.

\section{Apstrakt:}

\section{Faktori uticaja na nameravano ponašanje: Istraživanje korisnika usluga mobilnih operatera u Srbiji}

Vladimir Senić, Veljko Marinković

U oblasti uslužnog marketinga koncept percipirane vrednosti sve više zaokuplja pažnju autora i istraživača. Percipirana vrednost predstavlja multidimenzionalni kocept koji obuhvata veći broj različitih komponenti. U prezentovanoj studiji, analiziraju se četiri ključne komponente: emocionalna, društvena, funkcionalna i novčana vrednost. Cilj studije je bio da se odredi uticaj pomenute četiri komponente vrednosti na satisfakciju potrošača, kao i da se testira uticaj satisfakcije, društveno odgovornog ponašanja i korporativne reputacije na nameravano ponašanje potrošača na tržištu mobilne telefonije u Srbiji. Istraživanje počiva na pretpostavci da kada je cilj uspostavljanje dugoročnih odnosa s potrošačima, osim njihove satisfakcije, percipirana društvena odgovornost i reputacija kompanija takođe imaju veliki značaj.
Kontakt:

Vladimir Senić

Fakultet za hotelijerstvo i turizam Univerziteta u Kragujevcu Adresa: Vojvođanska 5A ,36210 Vrnjačka Banja email: vsenic@yahoo.com

Veljko Marinković

Ekonomski fakultet Univerziteta u Kragujevcu Adresa: Đure Pucara 3, 34000 Kragujevac email: vmarinkovic@kg.ac.rs 